\title{
Moradia escrava na era do tráfico ilegal: senzalas rurais no Brasil e em Cuba, c. 1830-1860'
}

Rafael de Bivar Marquese

Departamento de História da Faculdade de Filosofia, Letras e Ciências Humanas da Universidade de São Paulo

RESUMO: Há um bom tempo a historiografia sobre a escravidão nas Américas analisa o tema da moradia escrava. O debate nas últimas décadas tem girado em torno da discussão da autonomia escrava e do controle senhorial na construção desses espaços, centrando-se em especial na investigação das matrizes africanas das moradias rurais erigidas pelos cativos. Examino, no artigo, a novidade histórica representada por dois tipos específicos de moradia que apareceram após o segundo quartel do século XIX: o barracão de pátio do cinturão açucareiro cubano (na região de Matanzas-Cárdenas-Cienfuegos) e a senzala em quadra do Vale do Paraíba cafeeiro (no Centro-Sul do Império do Brasil). O trabalho demonstra que houve uma articulação histórica estreita entre esses dois arranjos arquitetônicos, passando pela apropriação de certas práticas do tráfico de escravos em solo africano.

PALAVRAS-CHAVE: Moradia escrava. Fazendas. Tráfico transatlântico. Controle social. Cuba. Brasil.

ABSTRACT: The subject of slaves' living quarters has been under the scrutiny of the historiography around Slavery in the Americas for a good while. The debate decades has revolved in the last few around the discussion on the slaves' autonomy and the master's control in the construction of such spaces, focusing in particular on the investigation of the African matrices present in the rural dwelling spaces built by the captives. I examine, in the article, the historic novelty represented by two specific types of dwelling spaces that emerged after the second quarter of the $19^{\text {th }}$ century: the patio shed of the Cuban Sugar Belt lin the region of Matanzas-CárdenasCienfuegos) and the square senzala of the river Paraíba Valley coffee region (in the MidSouthern region of the Brazilian Empire). The text demonstrates that there has been a historic articulation between these two architectural arrangements, and that it is related with the appropriation of certain slave trade practices in African territory.

KEYWORDS: Slave Housing. Plantations. Transatlantic Slave Trade. Social Control. Cuba. Brazil.
1. Este artigo faz parte de um projeto coletivo mais amplo que conta com o auxílio da The Getty Foundation.Agradeço a ajuda e os comentários de Dale Tomich, Paulo Garcez Marins, Marcos André Torres de Souza, Maria Cristina Wissenbach, Marina de Mello e Souza, Carlos A1berto Zeron, Carlos Bacellar, Fábio Joly, Rafael Valente e Ynaê Lopes dos Santos. 
2. Em resenha recente da tradução brasileira do livro clássico de Sidney Mintz e Richard Price (2003), procurei traçar um breve quadro dos estudos sobre a cultura afro-americana no século $\mathrm{XX}$, em especial a novidade trazida pela produção posterior à década de 1960. Ver MARQUESE, $2004 \mathrm{~b}$

3.Para uma visão geral des sas abordagens para os diferentes espaços escravistas do Novo Mundo, e sem qualquer pretensão de esgotar os títulos disponí veis, ver, para o Caribe in glês e francês, DEBIEN, 1974, p. 222-225; HIG MAN, 1995, p. 255-257 e CRATON, 1978; para os Estados Unidos, MORGAN, 1998, p. 104-124; GENO VESE, 1974, p. 524-535 e VLACH, 1993; para Cuba, RIVA, 1983 e FRAGINALS, 1987 ,v. 2, p. 87-97; para o Brasil, SILVA, 1990; FARIA 1993; AZEVEDO, 1994 CARRILHO, 1994; MELLO 2002 e SILVA, 2003.
Moradia escrava e historiografia

\begin{abstract}
Comecei a visitar velhas plantations do Sul basicamente para satisfazer minha curiosidade a respeito da organização física da escravidão. Também esperava adquirir alguma perspectiva histórica para meu trabalho como arquiteto afro-americano. Meu interesse pelo assunto retrocede a meados dos anos 1960, quando grande parte da atenção nacional voltou-se para o povo negro. Escritores, músicos e líderes políiticos afro-americanos estavam demonstrando à nação o quanto sua vida interior havia sido ignorada pelo fato de a experiência de sua população afro-americana ter sido silenciada (ANTHONY, 1976, p.8).
\end{abstract}

Essas palavras do arquiteto norte-americano Carl Anthony são bastante elucidativas a respeito do interesse que a historiografia passou a nutrir sobre a cultura escrava a partir da década de 1960. Com efeito, é certo que desde o início do século XX os historiadores prestaram atenção a temas como a família, a religião e a vida material dos escravos, mas somente com o boom da historiografia sobre a escravidão verificado após os anos sessenta é que a abordagem desses assuntos tomou corpo. Em resposta direta a questões sociais e políticas de seu tempo, os estudiosos passaram a pesquisar sistematicamente os vários aspectos da vida dos escravos africanos e de seus descendentes no Novo Mundo, encarando-os como sujeitos ativos na construção de seu devir².

A nova ênfase na agência escrava, por sua vez, permitiu a investigação aprofundada dos temas relativos à cultura material. No que se refere ao assunto deste artigo, a moradia escrava, pode-se afirmar que, nas três últimas décadas, consolidou-se na historiografia duas vertentes de análise, não raro empregadas simultaneamente pelos pesquisadores. Grosso modo, a primeira se ocupa dos modelos arquitetônicos das moradias escravas, isto é, suas origens, tipologias e técnicas construtivas, enquanto a segunda trata dos usos e apropriações escravas desses espaços. Ainda que as pesquisas disponíveis tratem de lugares e épocas variadas, nos últimos tempos vem se construindo certo consenso interpretativo sobre a questão. Os historiadores apontam que, quando tiveram oportunidade para tanto, os escravos configuraram suas moradias baseando-se em formas e técnicas africanas, exercendo assim considerável grau de autonomia na conformação de sua vida material ${ }^{3}$.

Um bom exemplo dessa perspectiva pode ser encontrado no livro recente de Robert Slenes, Na senzala, uma flor, cujo foco é a família escrava no Sudeste cafeeiro do Brasil oitocentista. Ao analisar os significados da organização familiar para os próprios cativos, o autor ressalta a importância que davam para a formação de núcleos familiares como arma na luta contra os senhores. O estabelecimento de laços conjugais estáveis, assim, Ihes facultaria maior autonomia para o controle de vários aspectos de sua vida material e cultural. Era isso, segundo o autor, o que ocorria com a moradia.

Baseando-se em relatos de viajantes que percorreram o Centro-Sul do Brasil ao longo do século XIX, Slenes distingue três tipos de vivenda escrava: as 
senzalas "pavilhão", edifício único com pequenos recintos ou cubículos separados para os escravos solteiros e casados, as senzalas "barracão", onde viveriam escravos e escravas solteiros em grandes recintos separados, e as senzalas "cabana", onde viveriam escravos casados ou solteiros de um mesmo sexo. Ao sintetizar sua análise sobre a questão, Slenes escreve que

o que chama a atenção na maioria destes depoimentos é que o casar-se [...] conferia acesso a um espaço construído próprio, seja um cubículo num barracão/pavilhão, seja num barraco separado. Mesmo não sendo necessariamente maior do que os cubículos [nos barracões], os compartimentos [nos pavilhões] ou os casebres dos solteiros, a moradia da pessoa casada - ou pelo menos da recém-casada, sem filhos - geralmente congregava menos gente [...]. Além disso, e mais importante, era uma habitação dividida com um parceiro de vida, não apenas de roça. Enfim, o casar-se freqüentemente implicava para o escravo ganhar mais espaço construído; mas, sobretudo, significava apoderar-se do controle desse espaço, junto com o cônjuge, para a implementação de seus próprios projetos (SLENES, 1999, p. 159).

Na seqüência, Slenes examina as matrizes arquitetônicas africanas das senzalas "cabana" construídas pelos escravos no Centro-Sul cafeeiro. Procedentes em grande parte da zona congo-angolana da África Central, esses cativos teriam recriado no Brasil várias das técnicas de construção empregadas em seu continente de origem, como o uso de paus de forquilha para a sustentação da cobertura, a adoção de um formato retangular para as cabanas, com teto de duas águas e cômodos pequenos, ou a ausência de janelas. Afora os elementos formais da construção, o sentido básico da moradia negra - "a definição de como se usavam espaços internos e externos" - teria permanecido o mesmo na passagem da África para o Brasil: a cabana não era o local de moradia em um sentido burguês, mas apenas o local do sono ou do abrigo contra as variações do tempo; o habitar, portanto, se desenrolaria antes no entorno da cabana do que no seu interior (SLENES, 1999, p. 149-180).

trabalho de Robert Slenes demonstra o proveito em se adotar uma perspectiva atlântica para o exame dos padrões de vida material escrava nas Américas. No entanto, deve-se ressaltar que não apenas as experiências dos escravos foram trazidas da África para o Novo Mundo, mas também as experiências dos poderes escravistas. Por ter enfocado mais a agência escrava do que a agência senhorial, Slenes deixou passar despercebida a novidade contida em certos arranjos de moradia que foram adotados em algumas das grandes fazendas de café do Vale do Paraíba. Refiro-me ao que a documentação coeva registra como senzala em quadra, isto é, edifícios contínuos erigidos em formato retangular e subdivididos em compartimentos ou cubículos, todos voltados para um terreiro ou pátio com entrada única guardada por um portão de ferro.

$\bigcirc$ que pretendo neste artigo é justamente analisar a novidade histórica representada pelas senzalas em quadra, sem me ocupar das apropriações escravas desses espaços. Contudo, para obter uma compreensão mais adequada das razões para a adoção desse modelo arquitetônico, é necessário examiná-lo em conjunto com os barracones cubanos, isto é, as grandes senzalas erigidas nos engenhos mecanizados e semimecanizados do cinturão açucareiro da colônia 
espanhola. As senzalas em quadra das fazendas de café brasileiras e os barracones dos engenhos de açúcar cubanos trouxeram uma ruptura substantiva em relação aos padrões de moradia escrava anteriormente existentes nas Américas, iá que negavam brutalmente a autonomia escrava em sua construção. Ademais, ambos os arranjos arquitetônicos surgiram em um mesmo momento, a década de 1840. Em um contexto de aceleração da produção de café e açúcar, aumento no volume do tráfico negreiro transatlântico ilegal e acirramento das tensões internas e externas em torno da escravidão, os grandes senhores brasileiros e cubanos recorreram a um modelo arquitetônico bastante difundido nas áreas litorâneas da África em que operavam seus respectivos traficantes.

Senzala em quadra e barracão de pátio

Os primeiros esforços sistemáticos para ordenar a moradia escrava apareceram na literatura agronômica do Caribe inglês e francês em fins do século XVIII, como parte de um impulso mais amplo de controle e otimização da força de trabalho cativa (MARQUESE, 2004a). Com efeito, são poucos os indícios disponíveis sobre a normatização da moradia escrava pelos proprietários rurais das diversas regiões de plantation do Novo Mundo antes do final do século XVIII. Houve, é claro, aqueles que cuidaram pessoalmente da construção das vivendas escravas, mas a regra parece ter sido a concessão de autonomia para os cativos erigirem esses espaços de acordo com seus próprios padrões culturais.

Para os autores caribenhos que escreveram sobre o assunto, o primeiro item que thes preocupou foi o estado sanitário das senzalas. As prescrições de Jean Baptiste Guisan - um engenheiro militar suíço com vasta experiência agrícola no Suriname, contratado na década de 1780 pelas autoridades francesas da Guiana para aí aplicar as técnicas agrícolas da colônia holandesa - são típicas a respeito do assunto. De acordo com Guisan, os alojamentos destinados aos cativos deveriam merecer atenção cuidadosa dos senhores. Em sua avaliação, os proprietários franceses (tanto os das ilhas caribenhas quanto os da Guiana) eram em geral displicentes em relação ao problema, deixando a construção das senzalas a cargo exclusivo dos escravos, que as erigiam conforme seus hábitos africanos, isto é, em casebres feitos de barro, madeira e palha, isolados uns dos outros e sem ordenação aparente. A prática dos holandeses no Suriname, contudo, era diferente. A construção das senzalas seguia o modelo das casernas, em edifício único com total simetria. Guisan advertiu que os escravos resistiam o quanto fosse possível ao modelo de moradia do Suriname, demonstrando nítida preferência por palhoças isoladas. A reforma das senzalas deveria atender em parte às demandas dos escravos, separando-as em alojamentos distintos para cada família ou casal; ao senhor, porém, competia certas interferências com vistas a garantir o máximo de salubridade possível. Assim, as senzalas deveriam 
ser erigidas unicamente em madeira, com certa elevação do solo para evitar a umidade excessiva e assegurar boa circulação do ar, e distribuídas de tal forma a evitar a comunicação de fogo de uma a outra (GUISAN, 1825, p. 245-247).

A reforma das senzalas, portanto, deveria tomar de empréstimo o modelo arquitetônico dos destacamentos militares. Esse impulso para a militarização da moradia escrava fica ainda mais evidente no trabalho de outro autor caribenho do período, P. J. Laborie, um grande produtor escravista de café de São Domingos. Laborie foi um daqueles senhores que, no curso da revolução escrava na década de 1790, apoiaram a invasão inglesa da colônia francesa como meio para restabelecer a ordem escravista. Para tanto, redigiu, com base em sua experiência de cafeicultor, o manual The Coffee Planter of Saint Domingo, destinado a guiar os eventuais investidores ingleses no processo de reconstrução da economia escravista da colônia. $\bigcirc$ projeto de Laborie foi derrotado com a vitória das tropas de ex-escravos comandadas por Toussaint L'Ouverture, mas seu manual persistiu como a principal referência agronômica sobre o assunto por todo o século XIX. A razão disso consistiu no fato de Laborie ter sintetizado as técnicas agronômicas que haviam garantido para São Domingos o posto de maior produtora mundial de café antes da Revolução Francesa.

$\bigcirc$ tratado foi dividido em quatro capítulos, que abordaram respectivamente a escolha e preparo dos terrenos para o plantio do café, a construção e distribuição dos edifícios, a cultura e processamento dos grãos e, por fim, a administração dos escravos. Dentro desse plano, Laborie dedicou atenção particular à organização espacial das plantations cafeeiras. Tanto é assim que o texto se fez acompanhar de várias pranchas nas quais eram apresentadas plantas arquitetônicas de grandes fazendas de São Domingos, com a indicação exata da localização dos edifícios, dos cafezais, das matas e dos pastos. Um cuidado especial foi reservado à exposição do plano de reforma da arquitetura da moradia escrava. Laborie propunha a construção das senzalas em linha, divididas em cubículos com 10 × 20 pés, cada qual reservado para três escravos; os cubículos, por sua vez, seriam subdivididos "em dois quartos, um, $A$, onde se faz o fogo, outro, B, para dormir. Pode-se acrescentar por detrás uma galeria, C, da largura de seis pés, para suas aves" (Figura 1).

Em sua organização interna, essas unidades seguiam claramente o padrão de moradia ioruba, adotado por grande parte dos escravos em São Domingos quando tinham a autonomia para tanto ${ }^{4}$. $\bigcirc$ sentido que Laborie thes imprimiu, contudo, foi outro. Um rápido exame da Figura 2 bem demonstra a filiação arquitetônica de suas senzalas às casernas européias. Sendo assim, o que buscou com a conjugação das diferentes unidades habitacionais escravas em edifícios únicos, simétricos e uniformes, dispostos de forma alinhada em torno dos terreiros de café ou em locais observáveis a partir da casa de vivenda senhorial, foi exatamente potencializar o controle senhorial sobre a morada dos cativos. Em suas palavras,
4. Como esclarece VLACH, 1990, p. 125 a respeito dessa filiação arquitetônica "o repertório arquitetônico ioruba é bastante extenso, com estruturas variando de casas simples a palácios. Mas, a despeito da variedade, todos os edifícios se baseiam em módulos de dois cômodos medindo $10 \times 20$ pés [...]. Essa casa de dois cômodos é essencial para o sistema arquitetônico ioruba e, conseqüentemente, não foi esquecida mesmo sob os rigores da escravidão". 


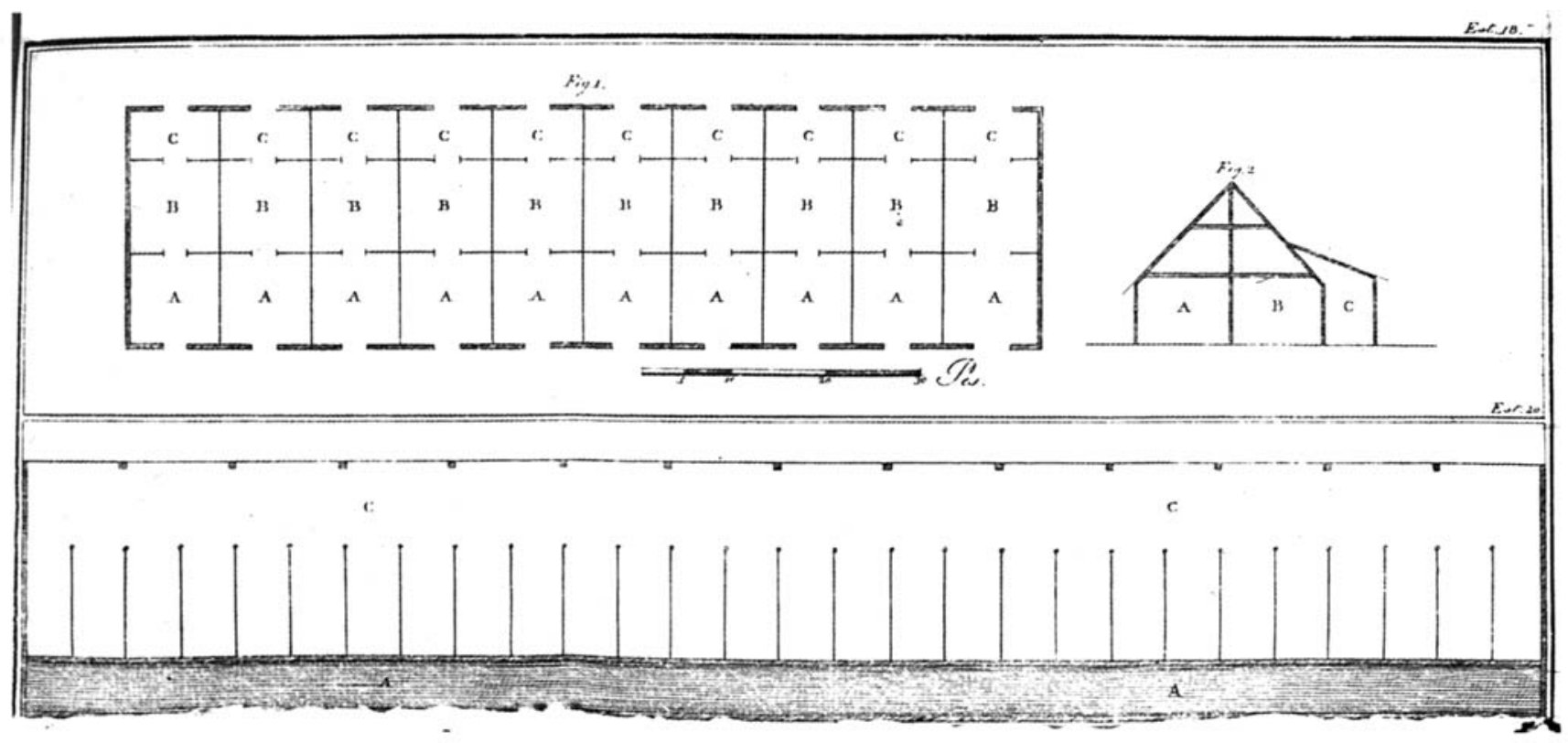

Figura 1 - Planta baixa e corte vertical da senzala proposta por P. J. Laborie (LABORIE, 1798). Acervo de Guita e José Mindlin, São Paulo. Reprodução de Hélio Nobre.

5.A tradução para o português foi realizada por Antonio Carlos Ribeiro de Andrada e publicada na coleção $O$ fazendeiro do Brasil (t. III, v. II), editada por Frei José Mariano da Conceição Veloso. Já a tradução espanhola foi feita por Pablo Boloix, sendo impressa em Havana com o título de Cultivo del cafeto, o arbol que produce el Café, y modo de beneficiar este fructo. as casas [...] devem ser de maneira situadas, que possa o senhor ver tudo, ouvir e dar ordem. A exação, e cuidado da manufatura, o serviço do hospital, que se deve guardar de dia, e de noite, a polícia das senzalas, e o cuidado do gado de toda a casta, inteiramente dependem da presença e vigilância do senhor (LABORIE, 1798, p.83) (Figura 2).

Para nossos fins, importa salientar que as prescrições desses autores antilhanos foram difundidas no Brasil e em Cuba na passagem do século XVIII para o XIX. Com efeito, dentro dos esforços para recuperar as respectivas posições de Portugal e Espanha no quadro internacional, os administradores ilustrados desses dois impérios elaboraram um amplo programa de reformas econômicas, com ênfase especial na questão da política colonial. Parte dessa política consistiu na tentativa de aplicar às colônias de plantation portuguesas e espanholas o receituário que havia garantido às possessões antilhanas de franceses e ingleses o posto de maiores produtoras mundiais de artigos tropicais. Sendo assim, vários dos textos agronômicos compostos para o Caribe francês e inglês foram traduzidos para o português e castelhano. Tal foi o caso do manual de Laborie, vertido para a primeira língua em 1800 e para a segunda em $1810^{5}$.

A despeito dessas traduções, os novos modelos de moradia escrava propostos pelos autores caribenhos não foram adotados nas plantations brasileiras e cubanas. Noutras palavras, antes da década de 1840, as unidades cafeeiras e açucareiras que foram montadas no Brasil e em Cuba mantiveram os padrões anteriores de habitação escrava. Tome-se o exemplo do Vale do Paraíba em fins da década de 1810 e inícios da de 1820, momento do deslanche da produção cafeeira na região. $\bigcirc$ naturalista francês Auguste de Saint-Hilaire, ao percorrer em 


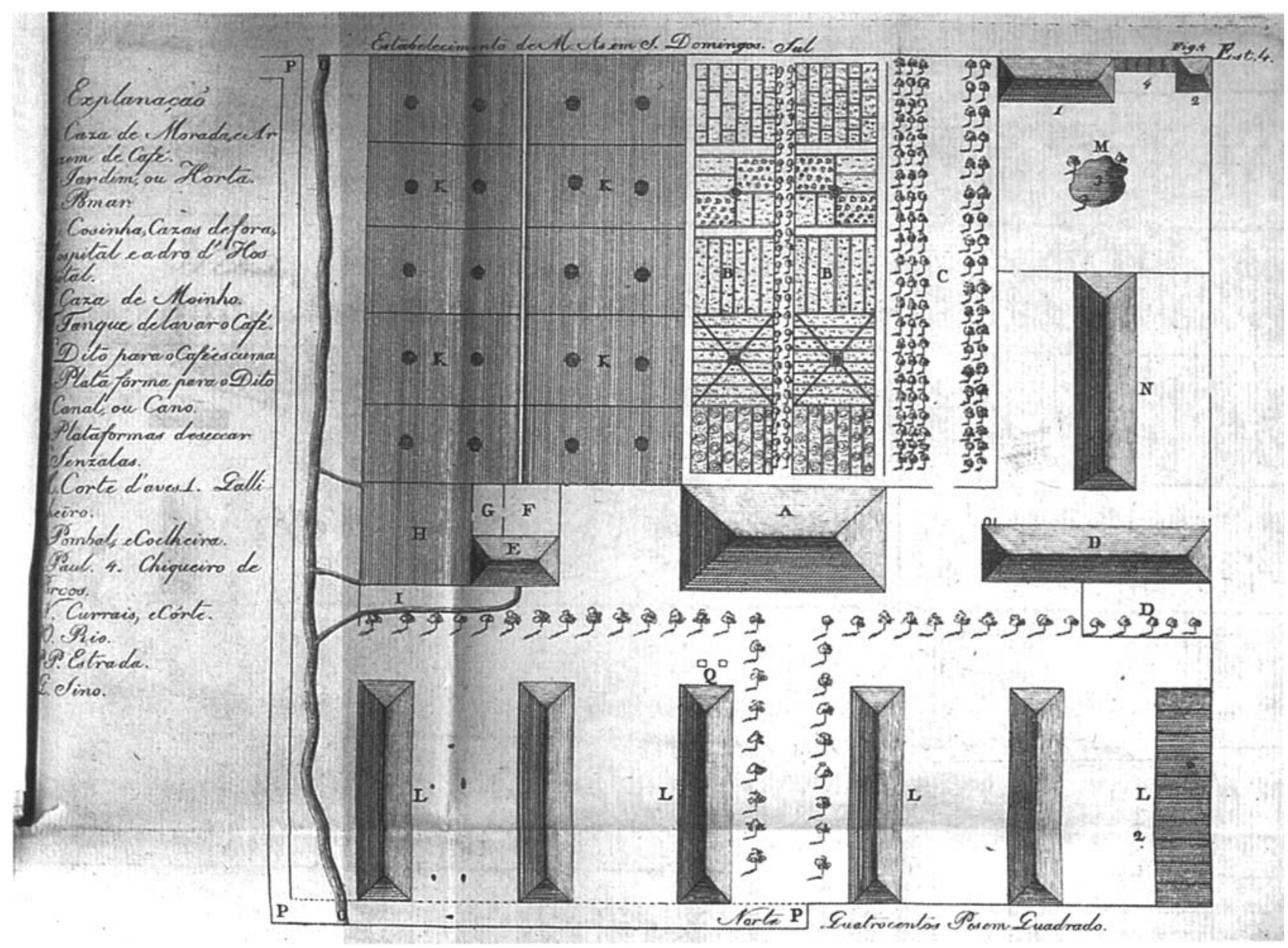

Figura 2 - Na legenda, A indica a casa de vivenda; L, as senzalas em linha, sendo que o último edifício à direita traz um corte horizontal com a indicação da existência de 10 cubículos em cada senzala (LABORIE, 1798). Acervo de Guita e José Mindlin, São Paulo. Reprodução de Hélio Nobre.

abril de 1822 o Caminho Novo da Piedade, retornando de São Paulo ao Rio de Janeiro, registrou, na altura da freguesia de Areias, as seguintes observações:

Hoje, comecei a notar, tanto à beira da estrada como a alguma distância, casas um pouco mais bem tratadas do que as vendas, e habitadas por agricultores mais abastados. Desde ontem começei a ver plantações de café, hoje mais numerosas. Devem aumentar mais ainda à medida que me for aproximando do Rio de Janeiro. Esta alternativa de cafezais e matas virgens, roças de milho, capoeiras, vales e montanhas, esses ranchos, essas vendas, essas pequenas habitações rodeadas das choças dos negros e as caravanas que vão e vem, dão aos aspectos da região grande variedade (SAINTHIILAIRE, 1974, p. 100).

A feição exata dessas "choças dos negros" - ou senzalas "cabana", para empregarmos a expressão cunhada por Robert Slenes - fica evidente se 
observarmos um outro registro do período. No desenho aquarelado de Thomas Ender, que percorreu o mesmo caminho de Saint-Hilaire cinco anos antes, podese ter uma idéia mais precisa do que eram essas "choças": o que se nota à esquerda da Figura 3 são casebres que seguem os padrões africanos de moradia escrava estudados a fundo por Slenes (Figura 3).

Esse parece ter sido o modelo das moradias escravas nas fazendas do Vale do Paraíba até a quarta década do século XIX. É certo que já na década de 1830 alguns fazendeiros estavam erigindo senzalas em linha nas unidades cafeeiras do Vale do Paraíba lo inventário do proprietário da Fazenda Cachoeirinha de Baixo, na vila de Bananal, São Paulo, dono de 26 escravos, registra em 1836 a existência de uma senzala contínua com sete lanços cobertos de telha) (CARRILHO, 1994, p. 62), mas até então não houve a deliberação para se construir um espaço diferenciado de habitação escrava. Nesse período, contudo, surgiu uma atenção mais detida com a normatização dos espaços de moradia nas fazendas. Isso pode ser observado com clareza nos manuais agrícolas publicados no período.

O exemplo mais significativo disso reside no trabalho de Francisco Peixoto de Lacerda Werneck, barão de Pati do Alferes. Ao publicar sua Memória sobre a fundação de uma fazenda na Província do Rio de Janeiro em 1847, primeiro nas páginas do periódico Auxiliador da Indústria Nacional e logo em seguida em livro, Werneck apresentou a síntese do saber escravista gestado nas fazendas de café do Vale do Paraíba (fluminense e paulista) na primeira metade do Oitocentos. Já na abertura do trabalho, ao traçar as instruções para a construção da senzala, Werneck recomendava cuidado com a saúde dos

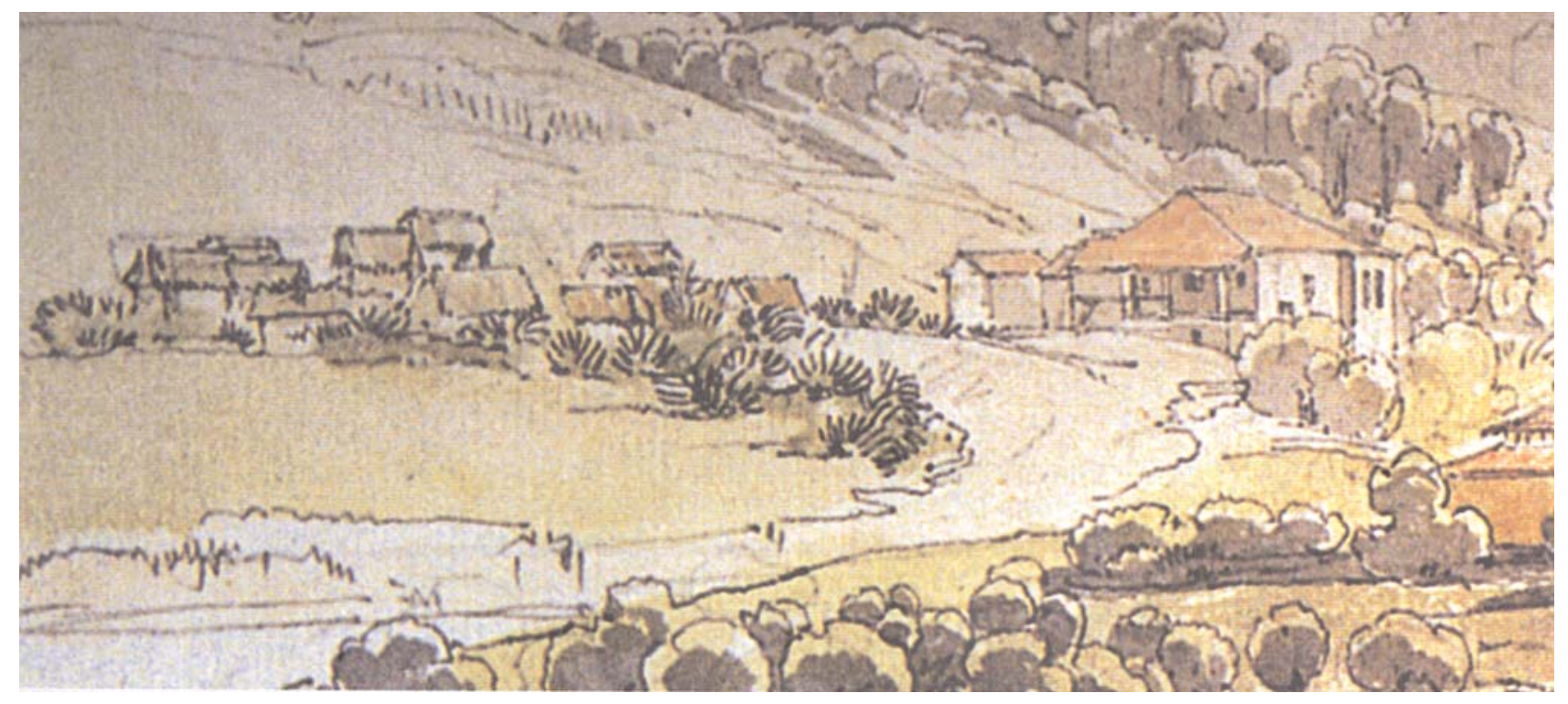

Figura 3 - Detalhe do desenho a lápis aquarelado de Thomas Ender, representando a fazenda do capitão Estevão, na passagem do Rio Piraí, pouco antes de se entrar na Província de São Paulo, 1817. (WAGNER, 2000, p. 805). Acervo do Gabinete de Gravuras da Academia de Belas Artes (Kupferstichkabinett der Academie der Bild Künst), Viena. 
escravos e vigilância estrita sobre eles. A senzala deveria ser erguida em uma só linha, num lugar sadio e enxuto, com quartos de 24 palmos quadrados e com uma varanda de oito palmos de largo em todo o seu comprimento; cada cubículo deveria acomodar quatro escravos solteiros, e, no caso dos casais, marido e mulher com os filhos. As portas dos cubículos estariam voltadas ao quadro da fazenda, que conformava uma espécie de pátio em torno do terreiro, sendo cada face ocupada respectivamente pela casa do senhor, pelos paióis, tulhas e cavalariças, pelos engenhos de pilões e de mandioca e pela senzala. A moradia escrava, assim, permaneceria sempre sob a vista e o controle do senhor (WERNECK, 1985, p.57-58).

A semelhança com algumas das plantas reproduzidas por Laborie é evidente. No entanto, o manual de Werneck deve ser lido à luz do que se começou a construir no Vale do Paraíba a partir da década de 1840. A novidade veiculada em seu trabalho consistiu no fechamento do terreiro, dispondo-se as senzalas em uma mesma quadra contínua à casa senhorial e aos edifícios da manufatura (engenhos, tulhas, etc.). Exatamente nesse período os inventários das fazendas começaram a registrar uma nova forma arquitetônica, denominada como "quadro de senzalas", ou "senzalas em quadra". Há um caso que ajuda a melhor iluminar o assunto. No inventário de 1855 da Fazenda das Antinhas (Bananal, São Paulo), com um total de 137 escravos, anotou-se a existência de "um quadro de senzalas com trinta lanços"6. Por si só, esse registro pouco esclarece, mas há uma pintura a óleo dessa propriedade, composta duas décadas após a realização do inventário, que muito auxilia a compreensão do arranjo arquitetônico (Figura 4).
6. Inventário post-mortem, padre Bento José Duarte, 1855.Juízo de Órfãos e Ausentes, Cartório do $1^{\circ}$ Ofício de Bananal, Museu Histórico e Pedagógico Major Novaes, Cruzeiro-SP. Como esclarece Carlos Lemos (1999, p. 24), "a palavra lanço [...] significava uma série de cômodos encarreirados, um atrás do outro, formando uma fila perpendicular à rua ou ao terreiro, quando se tratava de casa rural".

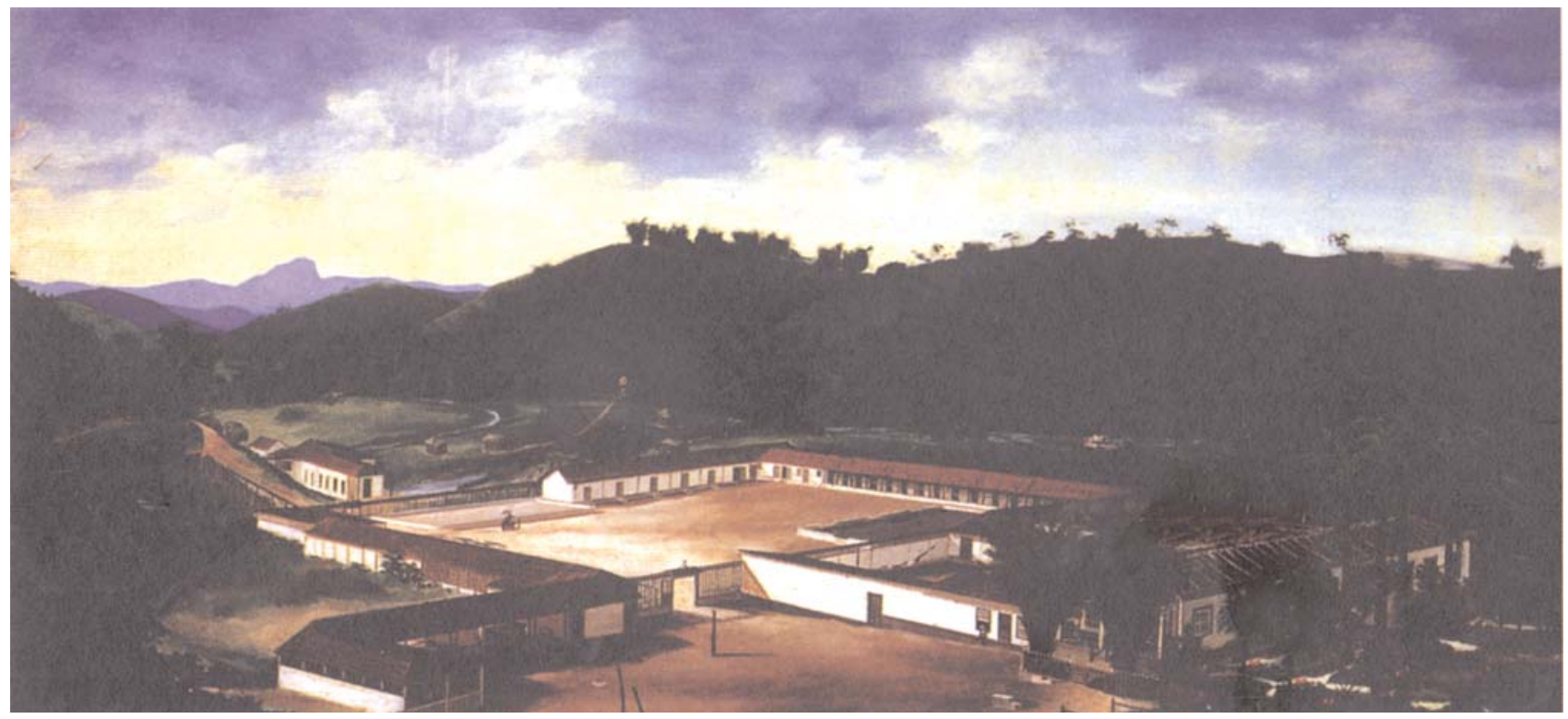

Figura 4 - José de Lima, Fazenda das Antinhas, Bananal, SP, óleo sobre tela, c. 1870, 90 × 163 cm. (SETUBAL, 2004, p. 160). Acervo de Maria Aparecida Rezende Gouveia de Freitas, São Paulo. Fotografia de Romulo Fialdini. 
7. Inventário post-mortem, comendador Luciano José de Almeida, 1854 Juízo de Órfãos e Ausentes, Cartório do $1^{\circ}$ Ofício de Bananal, Museu Histórico e Pedagógico Major Novaes, Cruzeiro-SP.
A disposição das senzalas em L, com as portas avarandadas e voltadas ao terreiro, é bem evidente ao fundo da imagem. A casa de vivenda localiza-se à direita, sendo que um muro a separa do terreiro. Do lado oposto ao da senzala, há mais uma construção em linha (possivelmente as tulhas com seis lanços, como indica o inventário de 1855). O que mais chama a atenção, no entanto, é o fato de o conjunto ser fechado: os vazios entre os edifícios são preenchidos com grades altas em balaústre, sendo que o único acesso ao terreiro - e às senzalas - é dado por um portão, visível na parte inferior esquerda da imagem.

Uma outra imagem, do mesmo período e da mesma região, é ainda mais esclarecedora quanto ao arranjo arquitetônico da senzala em quadra. Refirome à Fazenda Boa Vista, pertencente a Luciano José de Almeida, um notável cafeicultor de Bananal, dono de mais de 800 escravos quando de sua morte em 1854. Em seu inventário, há referência a dois conjuntos de senzalas em quadra na Fazenda Boa Vista, um com 49 e outro com 60 lanços $^{7}$. Observando-se a pintura a óleo dessa propriedade, percebe-se claramente qual a disposição das duas quadras. A primeira, com 60 lanços mais tulhas e engenho llocalizados na parte superior direita do terreiro), localizava-se em frente à casa de vivenda; a segunda, apenas com os lanços das senzalas, encontrava-se atrás. Na quadra frontal, nota-se novamente a existência de um único portão de entrada; todas as portas dos lanços da senzala, por sua vez, voltavam-se para o terreiro (Figura 5).

As senzalas em quadra, enfim, caracterizavam-se por seu isolamento, garantido por meio de sua disposição retangular, pelos compartimentos de habitação dos cativos que se comunicavam apenas com o terreiro, pela inexistência de janelas, pelos muros altos ou cercas em balaústres e pela entrada única fechada com portão. O estado atual das pesquisas indica que essa solução

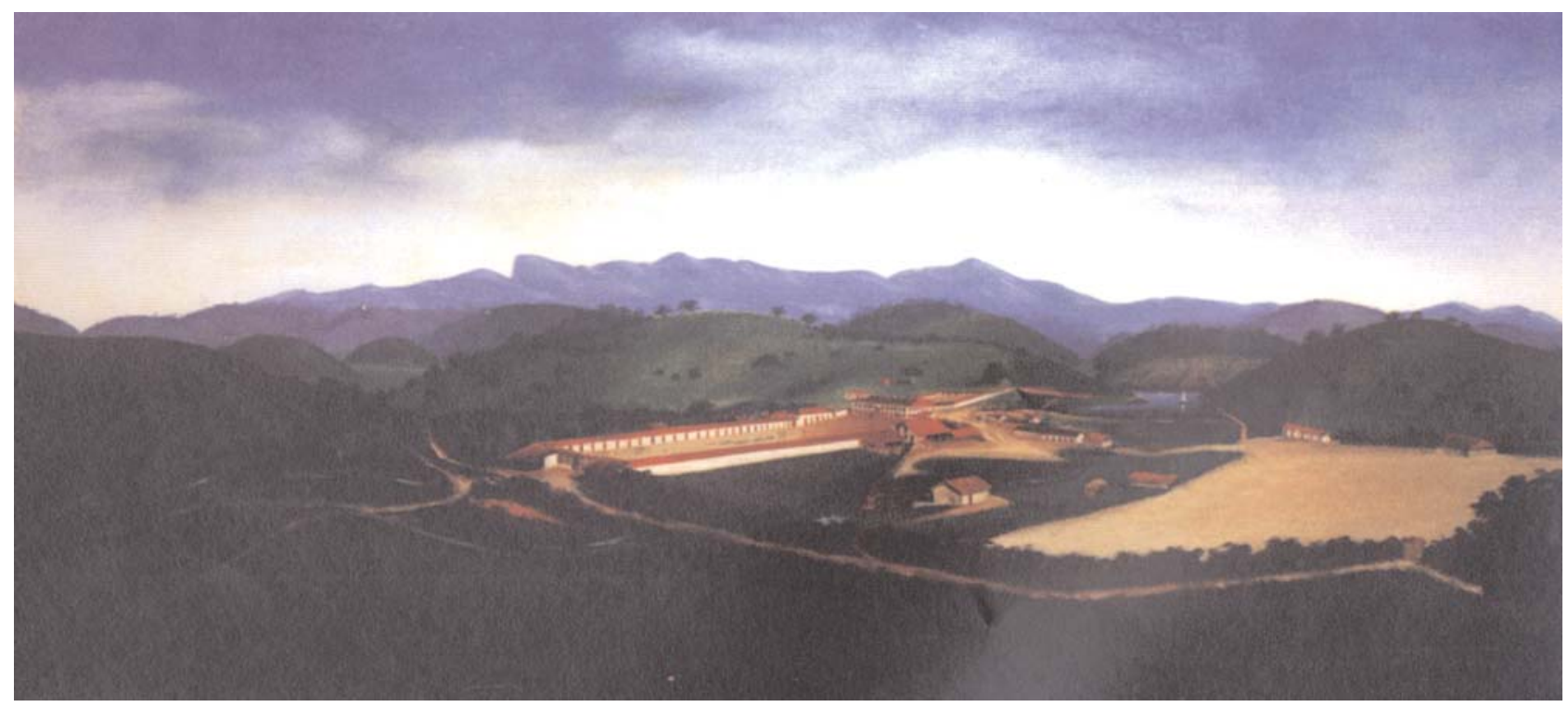

Figura 5 - Georg Grimm (atribuição), Fazenda Boa Vista, Bananal, SP, óleo sobre tela, c. 1880, 74 × 144 cm (SETUBAL, 2004, p. 160). Acervo dos descendentes de Dolores de Almeida Helou, São Paulo. Fotografia de Romulo Fialdini. 
arquitetônica foi uma disposição específica do Vale do Paraíba cafeeiro entre as décadas de 1840 e 1880, pois, com exceção de algumas grandes fazendas cafeeiras do Centro-Oeste paulista, não há registros de seu emprego em outras regiões escravistas de plantation no Brasil oitocentista ${ }^{8}$. As explicações que os estudiosos fornecem para sua adoção apontam para a herança da arquitetura rural do norte de Portugal. Nessa tradição, esclarece Carlos Lemos (1999, p. 29), a disposição dos edifícios em torno de um terreiro,

com os cômodos de serviço à volta, constitui a peça-chave da circulação, servindo não só de distribuição como de local de manipulação dos gêneros agrícolas. É onde a família portuguesa trabalha com os raros empregados, é o espaço muito bem definido e acessível por um só portão.

$\bigcirc$ terreiro à moda portuguesa, no Brasil, teria sido aplicado de início em Minas Gerais. Na passagem do século XVIII para o XIX, com a montagem da cafeicultura no Vale do Paraíba, o modelo teria sido disseminado por reinóis ou colonos vindos de Minas e adquirido sua configuração específica nas fazendas de café da região. Nessa interpretação, a inscrição das senzalas no terreiro da fazenda responderia antes à "necessidade de controle sobre as atividades no interior do quadro do que a formas rigorosas de confinamento" da mão-de-obra escrava (CARRILHO, 1994, p. 125).

Há, no entanto, uma outra explicação possível para a adoção das senzalas em quadra no Vale do Paraíba, que o caso cubano torna inteligível. Até a terceira década do século XIX, a moradia escrava típica das plantations cafeeiras e açucareiras de Cuba foi o bohío (palavra de origem taino), que mesclava elementos da arquitetura indígena com o padrão ioruba de moradia e não tinha qualquer interferência senhorial (VLACH, 1990, p. 125-127; WATTS, 1992, p. 106). Em meados dos anos 1820, algumas das autoridades coloniais e dos senhores de escravos cubanos passaram a defender a adoção de um novo modelo de vivenda para os escravos. Tal foi o caso de Cecilio Ayllon, governador, militar e político de Matanzas. Em 1825, a região foi agitada por uma série de revoltas escravas, notadamente em Guamacaro. Diante disso, Ayllon, "convencido da importância e necessidade de que seja uniforme o regime e governo interior das fincas rurais para afiançar melhor a segurança dos campos", consultou vários senhores da região sobre as medidas mais adequadas a serem tomadas para garantir a disciplina escrava. $\bigcirc$ resultado final foi um projeto para um código negro que recebeu o título de Reglamento de esclavos?.

Ayllon dividiu seu regulamento em quatro partes: medidas de segurança, obrigações dos senhores, normas penais e vigilância. A parte que mais interessa para os fins deste artigo é a primeira, que cuidou do controle disciplinar da escravaria. Seu princípio básico consistiu na incomunicabilidade total dos escravos com o mundo externo às plantations. Sendo assim, recomendava-se proibição expressa da entrada de homens de cor livres e brancos desconhecidos na plantation para a venda de gêneros aos cativos, bem como o pernoite de pessoas estranhas nos alojamentos dos escravos. Após a oração
8. São vários os exemplos de adoção de senzalas em quadra em grandes fazendas de café do Vale do Paraíba registrados em inventários. Para relatos de viajantes que as descreveram, ver, em relação à década de 1860 , TSCHUDI, 1980, p. 57-58 e, década seguinte, SMITH, 1941. Sobre a ausência de senzalas em quadra em outras regiões de plantation do Brasil oitocentista, ver os trabalhos de AZEVEDO e SILVA citados na nota 3. As aquarelas de antigas fazendas cafeeiras de Campinas que José de Castro Mendes compôs na década de 1940 documentam a presença de senzalas em quadra em algumas delas. Pela leitura do livro recente de FERRÃO, 2004 , p. 202-205, pode-se aventar a hipótese de ter havido filiação arquitetônica direta entre as senzalas em quadra do Vale do Paraíba e as que foram erigidas nas fazendas de Campinas a partir de meados do século XIX.

9. Sobre essa revolta, ver o trabalho recente de Manuel Barcia (2000). 
noturna das nove horas, o portão da finca seria trancado e os escravos impedidos de circularem dentro da propriedade. Os vigilantes brancos fariam de duas a três rondas noturnas, verificando se todos os escravos se encontravam descansando nas senzalas. Os instrumentos agrícolas de ferro seriam trancados à noite, e as armas de fogo pertencentes aos proprietários e brancos permaneceriam sempre guardadas e seguras. Em três anos, todas as propriedades com mais de 30 escravos deveriam substituir os bohíos independentes por senzalas de alvenaria, em edifício único, com alas separadas por sexo com uma só porta e trancas de ferro (AYLLON, 1825, p. 1-6).

$\bigcirc$ código de Ayllon pode ser entendido como uma das primeiras propostas formuladas em Cuba para a construção de um novo tipo de moradia escrava, capaz de aumentar o controle espacial dos trabalhadores. Honorato Bernado de Chateausalins, médico de origem francesa, certamente ajudou a difundir a nova planta arquitetônica proposta por Ayllon. Nascido em 1791, e formado em medicina pela prestigiosa Universidade de Paris, Chateausalins foi contratado pela família Drake, no início da década de 1820, para cuidar dos escravos de suas plantations cafeeiras em Cuba, na região de Matanzas. Chateausalins logo se tornou membro da Sociedade Econômica dos Amigos do País de Havana, e, calcado em sua experiência como médico de escravos, publicou, em 1831, El vademecum de los hacendados cubanos. $\bigcirc$ livro obteve grande sucesso entre os senhores de escravos cubanos, tendo sido reimpresso em 1848, 1854 e 1874.

Novamente, interessam aqui as orientações de Chateausalins a respeito da moradia escrava. Suas recomendações foram idênticas às do Reglamento de Ayllon, o que parece indicar a existência de um consenso a respeito do assunto, entre os senhores de Matanzas, a partir da década de 1830. Em substituição aos bohíos de barro cobertos com palhas,

sempre aconselharei que se fabriquem em forma de barracão com uma só porta aberta, cuidando o administrador ou feitor de recolher a chave pelas noites. Cada quarto que se fabrique, não terá outra entrada que uma só portinhola, e ao lado uma janela fechada com balaústres para que o negro não possa de noite comunicar-se com os outros (CHATEAUSALINS, 1848, p. 14).

Como se vê, Chateausalins empregou um novo vocábulo - barracão para se referir à moradia escrava que estava prescrevendo. Sua proposta e a de Ayllon para a construção de novas senzalas em substituição aos antigos bohíos, no entanto, não representava ainda uma ruptura significativa, pois se tratava de uma variação do edifício em linha prescrito pelos autores caribenhos ingleses e franceses de fins do século XVIII. A virada veio na década de 1840 e, como sugeriu o historiador Juan Perez de la Riva (1983, p. 16-30), conectouse diretamente ao aumento da resistência escrava. Nessa década, começou a ser erigido nos engenhos cubanos um novo tipo de moradia escrava, que se afastava profundamente dos padrões anteriores.

Para apreender essa novidade arquitetônica, cabe examinar algumas das publicações agrícolas cubanas de meados do século XIX que procuraram 
sistematizá-la. Tal é o caso do manual de Antonio de Landa, impresso em 1857 e reeditado com acréscimos em 1866, que pode ser tomado como o termo lógico de mais de 40 anos de reflexão sobre a gestão escravista em Cuba. Landa trabalhou 20 anos como administrador de engenhos na região de Matanzas, o centro da economia açucareira cubana até a década de 1860; seu livro, destinado à gestão de plantations pertencentes a proprietários absenteístas, pretendia apontar os erros mais comuns cometidos pelos administradores, indicar os meios para evitá-los e instruir os neófitos nos segredos da função.

A proposta de Landa para a moradia escrava seguiu claramente a inovação arquitetônica que apareceu na região de Matanzas na década de 1840, o barracão de pátio. Tratava-se de uma construção de alvenaria, em quadrilátero fechado em torno de um pátio e com uma única entrada com portão de ferro. Todos os cubículos onde dormiriam os escravos lque passaram a ser chamados de bohíos, termo anteriormente empregado para designar as choças independentes dos cativos) dariam para o pátio interno, sendo que cada um teria uma pequena janela gradeada para a entrada de ar e luz, também ela voltada para o pátio. Os bohíos seriam trancados após o toque de recolher, assim como o portão de ferro que dava acesso ao pátio. Os solteiros (escravos e escravas) ocupariam bohíos separados, enquanto os casais com filhos teriam bohíos específicos. No meio do pátio do barracão, haveria uma cozinha telhada, com no mínimo 30 varas de largura e sete de comprimento e mesas de tábuas, para os escravos lá comerem nos dias de chuva. Ao lado da cozinha, deveria ser aberto um poço para servir toda a escravaria; se isso não fosse possível, bastaria um tanque ladrilhado, abastecido por um canal pelo poço mais próximo. Em uma das faces internas do barracón, haveria ainda uma prisão, com os troncos destinados à punição dos escravos (LANDA, 1866, p.30-3 1) 10.

No manual de Landa, não foram inseridas imagens, mas outras publicações do período apresentaram plantas arquitetônicas detalhadas do barracão de pátio. Tal foi o caso de uma cartilha anônima publicada em 1862, que indicava em uma gravura bastante precisa quais seriam as dimensões ideais do edifício, suas divisões internas e externas e o desenho da fachada, seguindo, em linhas gerais, os mesmos elementos que haviam sido prescritos por Landa: entrada única (15), compartimentos separados para casados (9) e solteiros (10, 13), cozinha no centro do pátio (1) (Figura 6).

Tal como a senzala em quadra, que foi empregada apenas nas grandes fazendas de café do Vale do Paraíba, os barracões de pátio foram construídos sobretudo nos grandes engenhos mecanizados e semimecanizados de Cuba, montados a partir da década de 1840. Nessa época, os senhores cubanos mais capitalizados começaram a adotar técnicas que vinham sendo criadas na Inglaterra e França para o fabrico do açúcar de beterraba. Em substituição ao terno de caldeiras abertas, passaram a empregar caldeiras a vácuo, que aumentavam enormemente a produtividade do engenho e reduziam em muito a demanda de trabalho e combustível. As novas caldeiras aproveitavam a energia a vapor que era gerada para movimentar a moenda horizontal. Aliás, nesse período, um cubano inventou esteiras móveis que interligavam diferentes conjuntos
10. O barracão de pátio, portanto, representou uma solução arquitetônica distinta das vilas escravas cercadas por muros que SINGLETON, 2001, encontrou em plantations cafeeiras de Cuba. Como essa arqueóloga indicou, o controle e o cerceamento da autonomia escrava foram bem mais agudos nos barracões de pátio; de todo modo, o modelo para ambas soluções foram os barracões de embarque de escravos na Costa da África, algo que passou despercebido à autora. 


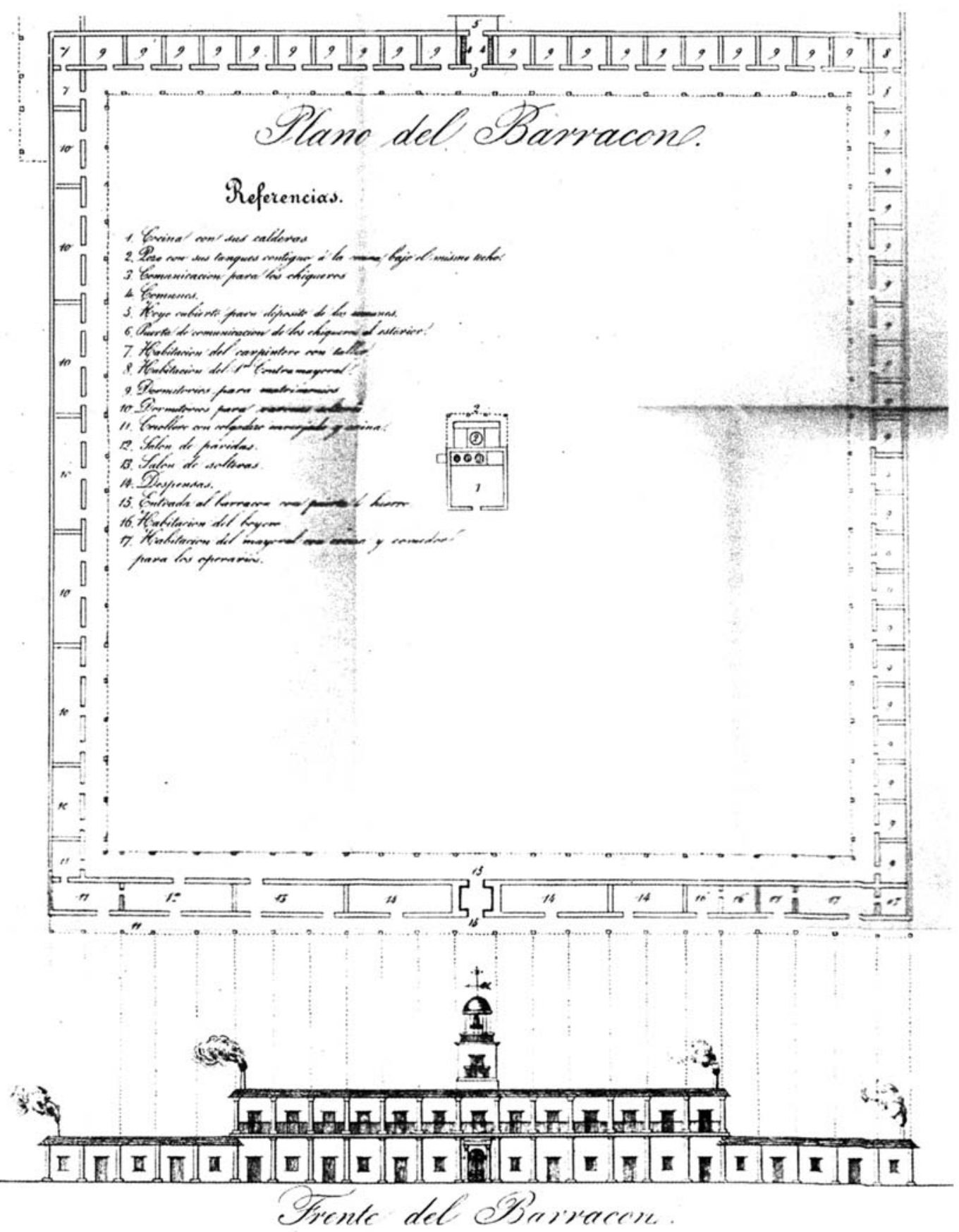

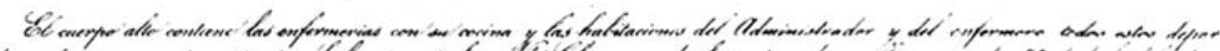

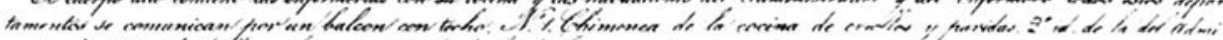

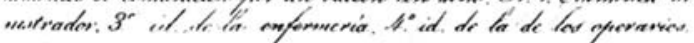

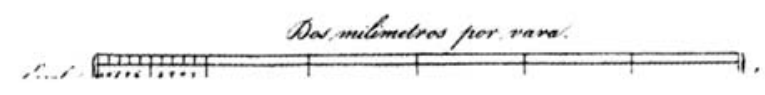

Figura 6 - Plano de um barracón cubano (CARTILLA, 1862). Acervo da Fondación Antonio Núñez Jiménez de la Naturaleza y el Hombre, Havana. 


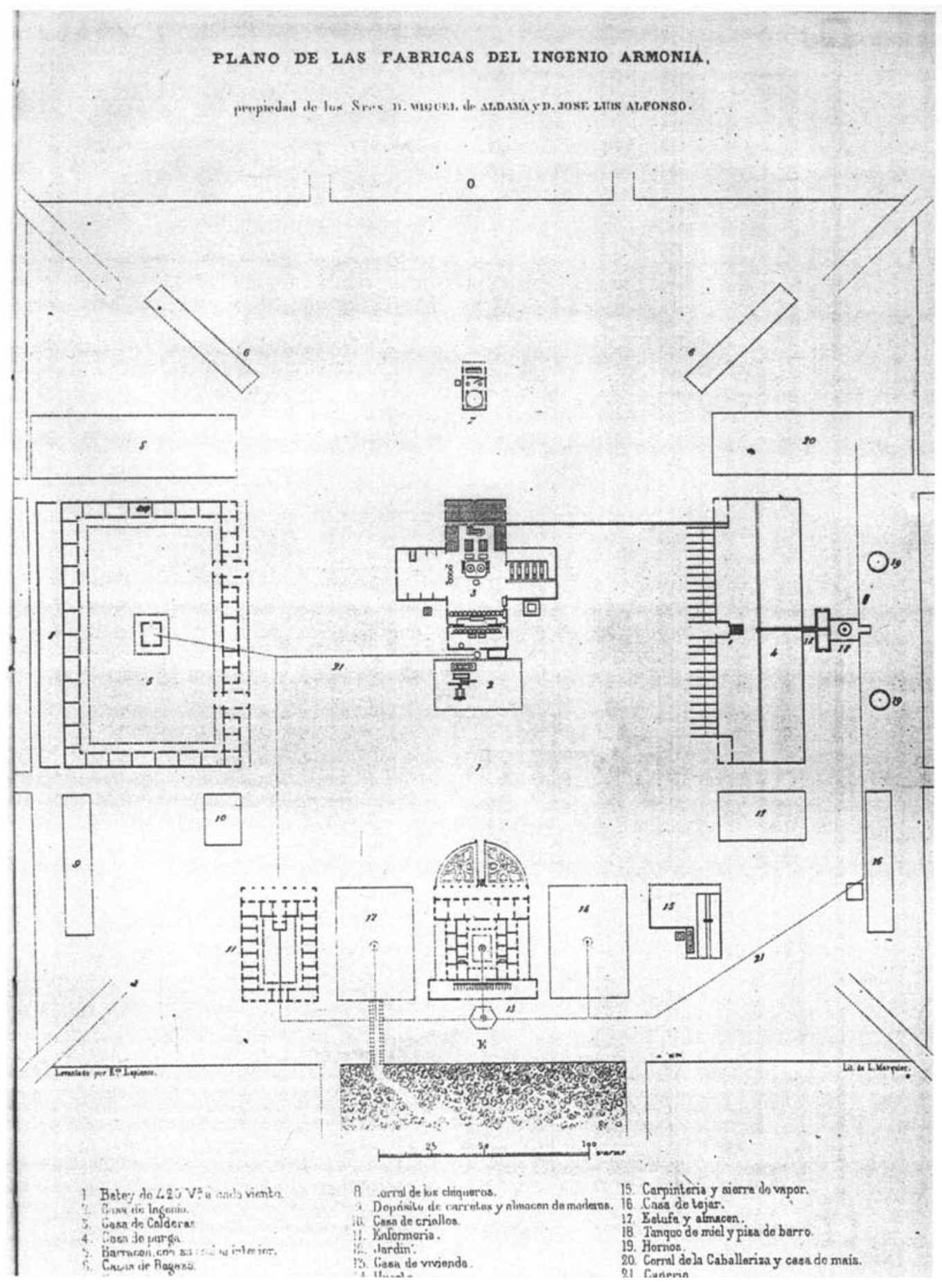

Figura 7 - Engenho Armonía. Litogravura de Eduardo Laplante. (CANTERO; LAPLANTE, 1857). Acervo da Fondación Antonio Núñez Jiménez de la Naturaleza y el Hombre, Havana. 
11. Sobre a revolução tecnológica dos engenhos cubanos, ver FRAGINALS 1987 , v.1, p. $211-237$ e KNIGHT, 1970, p. 25-46 Sobre as ferrovias cubanas, ver GARCÍA; ZANETTI, 1998, p. 1-56.

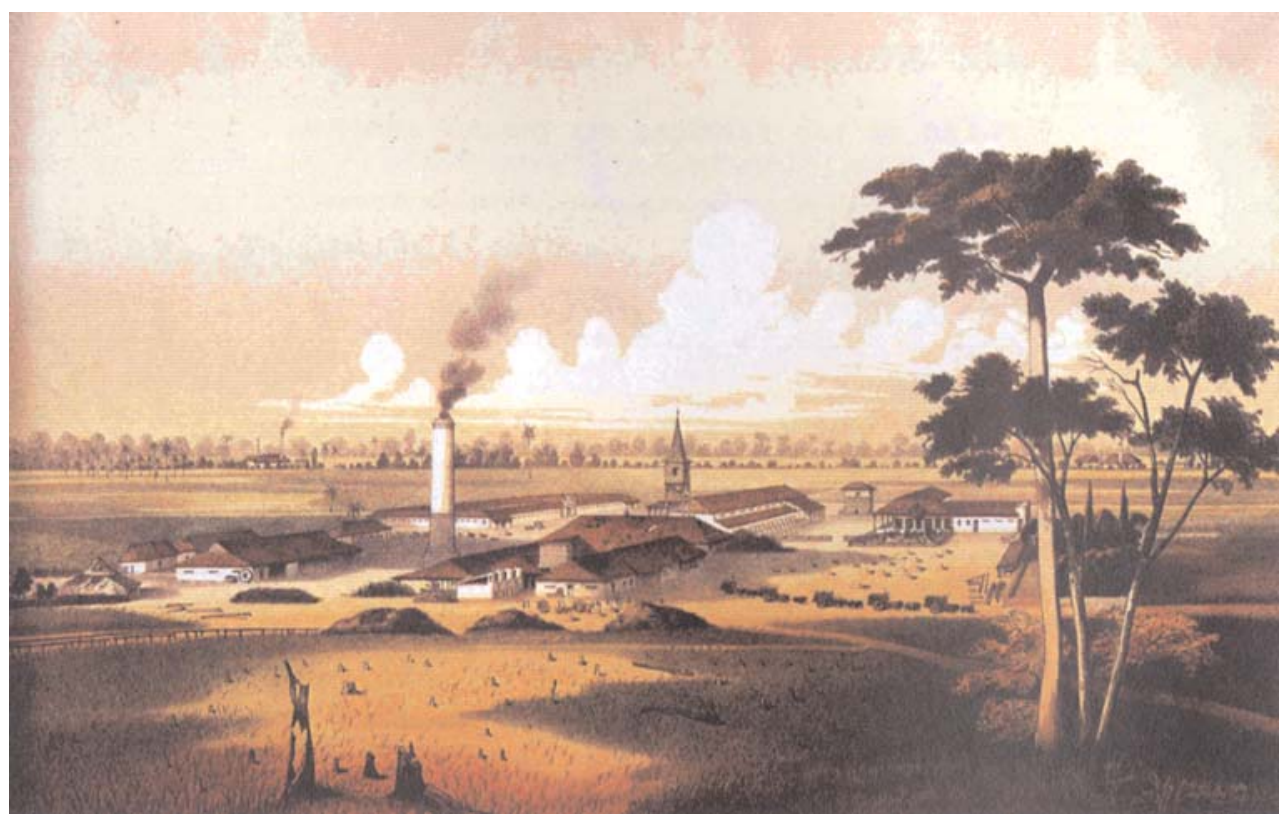

Figura 8 - Engenho Unión. $\bigcirc$ barracão de pátio, construído em alvenaria, localizava-se no alto esquerdo da imagem; a casa de vivenda se encontrava no lado oposto. Litogravura de Eduardo Laplante (CANTERO; LAPLANTE, 1857). Acervo da Fondación Antonio Núñez Jiménez de la Naturaleza y el Hombre, Havana.

de moendas horizontais, aumentando consideravelmente a capacidade de moagem de cana dos engenhos. No que se refere ao preparo final do produto, as centrífugas eliminaram o difícil e prolongado processo de purga necessário para a cristalização do açúcar. Por fim, não se pode esquecer da construção, a partir de 1837, da malha ferroviária cubana, que viabilizou o estabelecimento de engenhos afastados dos portos marítimos. As ferrovias, além de diminuírem os custos de transporte dentro da ilha, permitiram a ampliação da escala de produção das unidades açucareiras: a construção de trilhos dentro das maiores plantations facilitava e acelerava o transporte de cana para as moendas" ${ }^{11}$.

A combinação do emprego das moendas horizontais movidas a vapor, das caldeiras de múltiplo efeito a vácuo, das centrífugas e das ferrovias deu origem aos engenhos açucareiros completamente mecanizados de Cuba. Essas unidades se destacaram no contexto do escravismo moderno não apenas por sua tecnologia avançada, mas igualmente por sua força de trabalho numerosa: alguns desses engenhos chegaram a empregar de 400 a 500 escravos, afora uma quantidade considerável de collies chineses em regime de servidão temporária.

Para se ter uma idéia da inscrição dos barracões de pátio no espaço dos engenhos mecanizados, o registro mais adequado é a obra de Justo Cantero e Eduardo Laplante, que, em meados da década de 1850, apresentou um notável panorama das maiores unidades produtivas açucareiras de Cuba. $\mathrm{Na}$ planta reproduzida como Figura 7, que representa o Engenho Armonía, vê-se que o centro do espaço é ocupado pela casa das moendas e das caldeiras, 
complementada, à direita, pela casa de purgar. Abaixo, localiza-se a casa de vivenda senhorial, ladeada à direita pela serralharia e à esquerda pela enfermaria dos escravos. O barracão se encontra isolado, à esquerda do conjunto.

Portanto, ao contrário da senzala em quadra brasileira, que se articulava de forma estreita à casa senhorial por meio do terreiro de café, o barracão de pátio cubano era erigido como um edifício autônomo e afastado da casa de vivenda (Figura 8). Outra diferença importante se encontrava no sistema construtivo: enquanto os barracões cubanos eram de alvenaria, as senzalas brasileiras adotavam a técnica da taipa de mão. Essas distinções, entretanto, não escondem o que havia de comum aos dois arranjos de moradia escrava: a entrada única com portão, as trancas noturnas, os cubículos sem janelas, as pequenas frestas gradeadas, as portas todas voltadas ao pátio ou ao terreiro. Tratava-se, enfim, de uma solução espacial que cerceava brutalmente a autonomia escrava. Esses pontos em comum, além do mais, sugerem a existência de uma mesma matriz arquitetônica para a construção das senzalas em quadra no Brasil e dos barracões de pátio em Cuba.

Barracões africanos, tráfico ilegal e moradia escrava

Há um bom tempo os historiadores cubanos assinalam que o vocábulo barracón foi tomado de empréstimo das práticas do tráfico transatlântico de escravos. Na costa africana, a palavra designava as construções onde os cativos eram confinados antes do embarque nos navios negreiros. Algumas descrições contemporâneas ajudam a se ter uma idéia de sua arquitetura. Em sua memória sobre o tráfico de escravos em Angola, composta em 1793 e publicada em 1812, Luís Antônio de Oliveira Mendes (1977, p. 47) anotou que, ao chegarem ao litoral, os cativos eram "metidos em um pátio seguro, de altas paredes, que não podem pela mesma escravatura ser saltadas, ficando ali ao tempo; e de noite há um telheiro, ou armazém também térreos, aonde é recolhida". Com efeito, os barracões - ou quintais, expressão também utilizada pelos portugueses em Angola - caracterizavam-se por altos muros, erigidos em alvenaria ou com fortes paliçadas unidas por lâminas de ferro, e galpões dentro do cercado para abrigar os cativos das variações climáticas, sendo todo o conjunto vigiado por homens fortemente armados. Nos maiores edifícios, podiam ser acondicionados de quatro a seis mil escravos; nos menores, eram alocados de cem a seiscentos escravos ${ }^{12}$.

Barracões de escravos com tais características não foram exclusivos da costa angolana. $\bigcirc$ comandante da marinha inglesa Sir Henry Huntley, responsável pelo combate ao tráfico ilegal na costa da África Ocidental entre 1831 e 1838, registrou as seguintes observações a respeito dos barracões que o célebre traficante baiano Francisco Félix de Souza (o Chachá) mantinha no reino do Daomé:
12. Os historiadores que salientaram a unidade vocabular entre os barracões africanos e as senzalas cubanas foram ORTIZ, 1996, p. 75-76; RIVA, 1983, p. 18-19 e FRAGINALS, 1987 , v. 2, p. 96 . Para os barracões angolanos, ver, além da citação de Oliveira Mendes, os trabalhos de RODRIGUES, 2005, p. 67-71; LACROIX, 1977, p. 162-167 e MILLER, 1988, p. 387 401. 
perto da residência de De Souza estão os barracões ou depósitos de escravos, que são grandes espaços descobertos rodeados de muros ou de fortes paliçadas, no interior dos quais estão os abrigos para os negros no caso de mau tempo, durante o extremo calor do dia ou durante a noite. Ali estão freqüentemente reunidas numerosas centenas de jovens, de adultos, de homens e de mulheres (apud VERGER, 1987, p. 464).

Nada diferia os barracões de Chachá de seus congêneres em Luanda e Benguela, o mesmo podendo ser afirmado sobre os numerosos depósitos que traficantes hispano-cubanos como Pero Blanco e Julian de Zulveta mantinham no Senegâmbia e no Golfo de Guiné (FRANCO, 1980, p. 169, 178, 182, 200, 2011 . Além do mais, os barracões do tráfico de escravos guardaram muitas semelhanças formais e funcionais com os fortes e feitorias que os europeus estabeleceram desde o século XVI ao longo do litoral da África Ocidental. A gravura inserida no livro do padre francês Jean Baptiste Labat, referente às feitorias portuguesa, inglesa, francesa e holandesa em Savi, Daomé, bem o

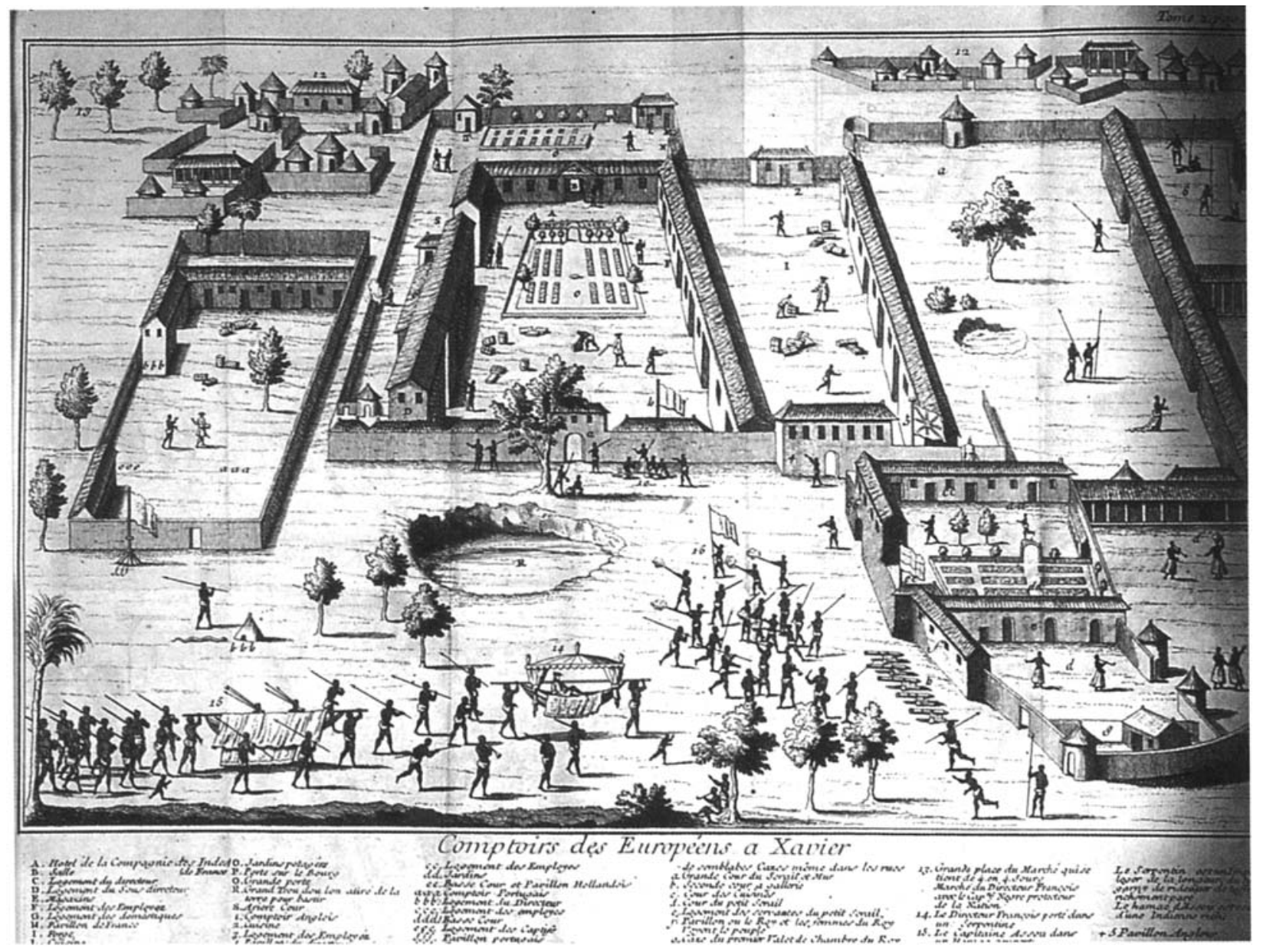

Figura 9 - Palácio Real e Feitorias Européias em Savi, Daomé, gravura (LABAT, 1730). Acervo do Instituto de Estudos Brasileiros da Universidade de São Paulo, São Paulo. Reprodução de Hélio Nobre. 
demonstra (Figura 9). Não obstante suas variações, barracões, fortes e feitorias eram compostos por muros altos e vigiados, com uma única entrada, e buscavam controlar de forma estrita enormes grupos de escravos antes do embarque nos navios negreiros.

Foi esse o princípio que governou a construção das senzalas em quadra do Vale do Paraíba e dos barracões de pátio de Cuba. A rigor, as vivendas escravas americanas aqui analisadas representaram uma reelaboração dos barracões da costa africana, e são as circunstâncias da adoção dessas soluções de moradia escrava que permitem falar em filiação arquitetônica direta.

No contexto da "era das Revoluções", o escravismo atlântico passou por uma alteração estrutural. O surgimento do movimento antiescravista, a crise do sistema colonial, a industrialização e a conseqüente expansão do mercado mundial de artigos tropicais trouxeram um enorme impacto para a escravidão negra nas Américas. As modificações ocorridas na economia internacional na passagem do século XVIII para o XIX impuseram aos senhores de escravos a necessidade do aumento constante da produtividade do trabalho de seus cativos, sob o risco de serem excluídos do mercado mundial. Isso levou, por um lado, à crise de antigas regiões produtoras como as Antilhas inglesas e francesas, acuadas por movimentos abolicionistas metropolitanos; por outro, à especialização produtiva das regiões escravistas das Américas que refundaram a instituição a partir de novos arranjos políticos. Assim, o arranque da cafeicultura brasileira, com a elevação de sua produtividade, colocou em cheque a cafeicultura cubana; a especialização dos produtores escravistas de Cuba na economia açucareira, por sua vez, foi um dos fatores centrais da crise da produção de açúcar do Brasil (TOMICH, 2004).

De todo modo, o motor do crescimento da produção escravista brasileira e cubana na primeira metade do século XIX foi, sem sombra de dúvidas, o tráfico transatlântico de escravos, que cresceu de forma inaudita para essas duas regiões após 1808. Nessa data, além de o comércio negreiro transatlântico ter se tornado monopólio português e espanhol (no ano anterior, o tráfico para as colônias inglesas e para os Estados Unidos havia sido abolido), Brasil e Cuba se conectaram diretamente ao mercado mundial, por conta da abertura dos portos brasileiros e do fato de a Espanha ter perdido, no contexto das guerras napoleônicas, o controle comercial sobre suas possessões americanas. No entanto, após 1815, Portugal e Espanha tiveram que fazer frente a uma fortíssima pressão diplomática da Inglaterra pela abolição do tráfico transatlântico de escravos. Em 1820, os ingleses conseguiram arrancar dos espanhóis a proibição legal do comércio negreiro, o mesmo ocorrendo em 1831 com os brasileiros, que, após a independência, herdaram de Portugal todo o problema político a respeito do assunto (BLACKBURN, 2002).

Não obstante esses decretos que aboliam o tráfico nas letras da lei, - comércio negreiro brasileiro e cubano, entre as décadas de 1820 e 1850, prosseguiv e cresceu na ilegalidade, assim como as gestões inglesas sobre os impérios do Brasil e da Espanha para que o encerrassem de forma definitiva. A resposta brasileira e hispano-cubana, por sua vez, foi relativamente uniforme, o 
13. Para a articulação entre tráfico negreiro e montagem da cafeicultura no Brasil, ver FRAGO SO; FLORENTINO, 1993 ; para Cuba, ver FRAGI NALS, 1995, p. 190-205. Sobre o envolvimento de Luciano José de Almeida no tráfico, ver ABREU, 1995. Sobre Aldama e Alfonso, ver BARCÍA; TOR RES-CUEVAS, 1994, p 410-411 que demonstra a unificação política, geográfica e operacional do tráfico negreiro transatlântico no século XIX. No plano diplomático, as autoridades brasileiras e hispano-cubanas recorreram a uma mesma argumentação e estratégia. No plano concreło do tráfico, os mercadores brasileiros e hispano-cubanos não só ałuaram de forma conjunta nas mesmas regiões da costa da África (zona congo-angolana e costa da Mina; a exceção foi a costa da Alta Guiné, na qual agiram apenas os hispano-cubanos) como elaboraram novas modalidades de gestão do negócio, com operações articuladas e sofisticadas que com freqüência envolviam praças comerciais em três continentes distintos (Rio de Janeiro, Salvador, Havana, Nova lorque, Londres, Sevilha, Lisboa, afora os diversos portos africanos) e buscavam burlar a vigilância naval inglesa (VERGER, 1987; CONRAD, 1985; ELTIS, 1987; TAVARES, 1988; AMARAL, 1999; SILVA, 2004).

Nessas operações, os barracões africanos desempenharam grande importância. A forma arquitetônica havia sido aplicada desde o século XVI para controlar o risco de revoltas de escravos ainda em solo africano. Com o endurecimento da política antiescravista pela Inglaterra, que montou uma esquadra sediada em Serra Leoa destinada exclusivamente ao combate e à captura dos negreiros, os barracões adquiriram uma outra função, qual seja, a de apressar o ritmo do circuito do tráfico. Como assinala Robin Law (1998, p. 102)

o armazenamento de escravos [em barracões] em antecipação ao embarque, apesar de ser realizado antes, tornou-se uma prática bem mais comum na era do tráfico ilegal, dada a necessidade de acelerar a partida dos navios negreiros para minimizar os riscos de interceptação.

A sofisticação dos negócios negreiros não ocorreu apenas no lado africano do Atlântico. Em Cuba e no Brasil, os traficantes diversificaram consideravelmente seus investimentos ao longo do século XIX. Uma parcela considerável das fortunas cafeeiras do Vale do Paraíba teve origem no tráfico de escravos. Na colônia espanhola, a imbricação entre o setor agroexportador e o tráfico transatlântico foi ainda mais profunda: as ferrovias - que permitiram a ampliação da fronteira açucareira - e os grandes engenhos mecanizados foram em grande parte financiados com capitais amealhados no tráfico ilegal de africanos. Dois exemplos são particularmente significativos para o que se está discutindo aqui: Luciano José de Almeida, proprietário da Fazenda Boa Vista, envolveu-se diretamente com o tráfico ilegal, como comprova seu papel no "caso do Bracuhy", em 1852; Miguel de Aldama e José Luis Alfonso, donos do Engenho Armonía, tinham participação ativa no comércio negreiro transatlântico para Cuba ${ }^{13}$

Nas décadas de 1830 e 1840, diante do aumento da pressão inglesa, da aceleração do tráfico ilegal, do incremento da exploração da força de trabalho para responder à demanda do mercado mundial e do aumento da resistência escrava - a revolta dos Malês e a conspiração de La Escalera, eventos fundamentais para a conformação da consciência senhorial brasileira e cubana no século XIX, ocorreram exatamente nesse período (REIS, 2003; PAQUETTE, 1988) -, os fazendeiros de café e os senhores de engenho no Brasil e em Cuba se viram ante 
a necessidade de aumentar o controle sobre seus cativos. Para tanto, o modelo do barracão africano, uma solução arquitetônica bastante familiar para alguns dos grandes proprietários escravistas brasileiros e cubanos, muito tinha a oferecer.

$\mathrm{Na}$ passagem pelo Atlântico, o modelo recebeu modificações relevantes. Enquanto os barracões foram a norma na costa africana, as senzalas em quadra e os barracões de pátio encontraram pouca difusão no Brasil e em Cuba. Apenas os grandes engenhos cubanos mecanizados e semimecanizados os adotaram, o mesmo ocorrendo no Vale do Paraíba, onde somente fazendas com mais de 100 escravos - que não eram a regra, mas sim a exceção - o fizeram. A permanência dos cativos nos barracões africanos era breve, os cuidados com a higiene do local, mínimos, e o agrilhoamento, bastante comum; além do mais, para acolher os escravos das variações climáticas, havia apenas pequenas coberturas feitas de palha. Já as senzalas em quadra e os barracões de pátio eram concebidos como moradias permanentes. Por essa razão, a preocupação com a higiene era bem maior, os materiais de que eram feitas, mais consistentes, e, acima de tudo, os cubículos que abrigavam os escravos pressupunham a existência de uma comunidade com relações familiares estabelecidas.

As diferenças, entretanto, não escondem a filiação: a forma retangular, o muramento, a entrada única e a supervisão estrita estiveram presentes nos dois lados do Atlântico ${ }^{14}$. O impulso básico para a adoção de um modelo arquitetônico do tráfico transatlântico nas plantations cafeeiras e açucareiras do Brasil e de Cuba foi a militarização da moradia escrava, vista como um meio capaz de ajudar a conter a escravaria em um contexto externo e interno profundamente tenso. Nesse sentido, as senzalas em quadra e os barracões de pátio deram continuidade à normatização dos autores antilhanos de fins do século XVIII, mas de um modo muito mais acentuado e explícito.

\section{REFERÊNCIAS}

ABREU, M. O caso do Bracuhy. In: CASTRO, H. M. M. de; SCHNOOR, E. (Orgs.). Resgate. Uma janela para o Oitocentos. Rio de Janeiro:Topbooks, 1995.

AMARAL, R. do. Brasil e Angola no tráfico ilegal de escravos, 1830-1860. In: PANTOJA, S.; SARAIVA, J. F. S. (Orgs.). Angola e Brasil nas rotas do Atlântico Sul. Rio de Janeiro: Betrand Brasil, 1999.

ANTHONY, C.The Big House and the Slave Quarters. Part I. Prelude to New World Architecture. Landscape, San Francisco, v. 20, n. 3, p.8-19, 1976.

AZEVEDO, E. B. de. Açúcar amargo. A construção de engenbos na Babia oitocentista. 1994. 272f. Tese (Doutorado) - Faculdade de Arquitetura e Urbanismo, Universidade de São Paulo, São Paulo, 1994.

AYLLON, C. Reglamento de esclavos. Matanzas, 1825.

BARCIA, M. La rebelión de esclavos de 1825 en Guamacaro. 2000. Dissertação (Mestrado) Casa de Altos Estudos Fernando Ortiz, Universidade de Havana, Havana, 2000.
14. Sendo assim, é completamente carente de fundamento a hipótese de Gomes da Silva e Azevedo a respeito da matriz do compound ioruba para a forma do barracão de pátio cubano: primeiro, pelo fato de o compound não ter entrada única, segundo, por se organizar a partir do princípio da família extensa.Ver, desses autores, os trabalhos citados na nota 3 . Sobre o compound, ver CUNHA, 1985, p. 87-89. 
BARCÍA, M. del C.;TORRES-CUEVAS, E. El debilitamiento de las relaciones sociales esclavistas. Del reformismo liberal a la revolución independentista. In: BARCÍA, M. C.; GARCÍA, G.; TORRESCUEVAS, E. (Orgs.). Historia de Cuba. La Colonia. Evolución socioeconómico y formación nacional. La Habana: Editora Política, 1994.

BLACKBURN, R. A queda do escravismo colonial, 1776-1848. São Paulo: Record, 2002.

CANTERO, J.; LAPLANTE, E. Los ingenios. Colleción de vistas de los principales ingenios de azúcar de la Isla de Cuba. Havana: Impr.Luis Manquer, 1857.

CARRILHO, M. J. As fazendas de café no Caminbo Novo da Piedade. 1994. 166f. Dissertação (Mestrado) - Faculdade de Arquitetura e Urbanismo, Universidade de São Paulo, São Paulo, 1994.

CARTILLA practica del manejo de ingenio ó fincas destinadas á producir azúcar. Irun: Imprenta de la Elegancia, 1862.

CHATEAUSALINS, H. B. de. El vademecum de los hacendados cubanos. Filadélfia, 1848.

CONRAD, R. E. Tumbeiros. O tráfico de escravos para o Brasil. São Paulo: Brasiliense, 1985.

CRATON, M. Searching for the invisible man. Slaves and plantation life in Jamaica. CambridgeMass: Harvard University Press, 1978.

CUNHA, M. C. da. Da senzala ao sobrado.Arquitetura brasileira na Nigéria e na República Popular do Benim. São Paulo: Nobel/Edusp, 1985.

DEBIEN, G. Les esclaves aux Antilles Françaises (XVIIe au XVIIIe siècles). Basse Terre: Société d'Histoire de la Guadeloupe, 1974.

ELTIS, D. Economic Growth and the Ending of the Transatlantic Slave Trade. New York: Oxford University Press, 1987.

FARIA, S. S. de C. Fontes textuais e vida material: observações preliminares sobre casas de moradias nos campos dos Goitacazes, sécs.XVIII e XIX. Anais do Museu Paulista. História e cultura material, São Paulo, Nova Série, n. 1, p.107-129, 1993.

FERRÃO,A. M. de A. Arquitetura do café. Campinas: Ed.Unicamp; São Paulo: Imprensa Oficial, 2004.

FRAGINALS, M. M.O engenbo:complexo sócio-econômico açucareiro cubano. São Paulo:HucitecUnesp, 1987, 2v.

Cuba/España, España/Cuba: Historia común. Barcelona: Crítica, 1995.

FRAGOSO,J.; FLORENTINO, M. O arcaísmo como projeto:mercado atlântico, sociedade agrária e elite mercantil no Rio de Janeiro, c. 1790-1840. Rio de Janeiro: Diadorim, 1993.

FRANCO, J. L. Comercio clandestino de esclavos. Havana: Editorial de Ciencias Sociales, 1980.

GARCÍA,A.; ZANETTI, O. Sugar and Railroads. A Cuban History, 1837-1959. Chapel Hill:The University of North Carolina Press, 1998.

GENOVESE, E. Roll, Jordan, Roll.The World the Slaves Made. New York:Vintage, 1974. 
GUISAN, J. S. Traité sur les Terres Noyées de Ia Guyane. Cayenne, 1825.

HIGMAN, B. W. Slave Populations of the British Caribbean, 1807-1834. Barbados:The Press University of West Indies, 1995.

KNIGHT, F.W. Slave Society in Cuba during the Nineteenth Century. Madison:The University of Wiscousin Press, 1970.

LABAT, J. B. Voyage du chevalier des marchais en Guinée, Isles Voisines, et a Cayenne, fait en 1725,1726 \& 1727. Paris, 1730.

LABORIE, P. J. The Coffee Planter of Saint Domingo. Londres, 1798.

LACROIX, D. Les Derniers négriers. Paris: Ed.Maritimes et d`outre Mer, 1977.

LANDA,A. de. El administrador de ingenio. Havana, 1866.

LAW, R. Barracoons. In: FINKLEMAN, P.; MILLER, J. C. (Eds.). Macmillan Encyclopedia of World Slavery. New York: Simon \& Schuster Macmillan, 1998, $2 \mathrm{v}$.

LEMOS, C. Casa paulista. História das moradias anteriores ao ecletismo trazido pelo café. São Paulo: Edusp, 1999.

MARQUESE, R. de B. Feitores do corpo, missionários da mente. Senbores, letrados e o controle dos escravos nas Américas, 1660-1860. São Paulo: Companhia das Letras, $2004 a$.

. História, antropologia e a cultura afro-americana: o legado da escravidão. Estudos Avançados, São Paulo, v.18, n. 50, p. 303-308, 2004 b.

MELLO, E. C. de. Um enigma iconográfico. In: MELLO, E. C. de. Um imenso Portugal. História e bistoriografia. São Paulo: Editora 34, 2002.

MENDES, L.A. de O. Memória a respeito dos escravos e tráfico da escravatura entre a Costa d'África e o Brasil. Lisboa: Escorpião, 1977.

MILLER, J. C. Way of Death. Merchant Capitalism and the Angolan Slave Trade, 1730-1830. Madison:The University of Wisconsin Press, 1988.

MINTZ, S.; PRICE, R. O nascimento da cultura afro-americana. Uma perspectiva antropológica . Rio de Janeiro: Pallas/Universidade Cândido Mendes, 2003.

MORGAN, P. Slave Counterpoint. Black Culture in the Eighteenth-Century Chesapeake E Lowcountry. Chapel Hill: University of North Carolina Press, 1998.

ORTIZ, F. Los negros esclavos. Havana: Editorial de Ciencias Sociales, 1996.

PAQUETTE, R. L. Sugar is Made with Blood. The Conspiracy of La Escalera and the Conflict between Empires over Slavery in Cuba. Middletown, Conn:Wesleyan University Press, 1988.

RIVA, J. P. de la. El barracón: esclavitud y capitalismo en Cuba. Barcelona: Editoral Crítica, 1983.

REIS, J. J. Rebelião escrava no Brasil. A história do levante dos Malês em 1835, 3ª ed. São Paulo: Companhia das Letras, 2003.

RODRIGUES, J. De costa a costa: escravos, marinbeiros e intermediários do tráfico negreiro de Angola ao Rio de Janeiro (1780-1860). São Paulo: Companhia das Letras, 2005. 
SAINT-HILAIRE,A. de. Segunda viagem do Rio de Janeiro a Minas Gerais e a São Paulo - 1822. Belo Horizonte: Itatiaia; São Paulo: Edusp, 1974.

SETUBAL,M.A.(Coord.).Modos de vida dos paulistas:identidades, famílias e espaços domésticos. São Paulo: Cenpec; Imprensa Oficial, 2004. (Coleção Terra paulista: histórias, arte, costumes, v. 2).

SLENES, R. W. Na senzala, uma flor. Esperanças e recordações da família escrava - Brasil Sudeste, século XIX. Rio de Janeiro: Nova Fronteira, 1999.

SILVA,A. da C.e. A casa do escravo e do ex-escravo. In: SILVA,A. da C. e. Um rio chamado Atlântico. A África no Brasil e o Brasil na África. Rio de Janeiro: Nova Fronteira / Ed.UFRJ, 2003.

2004 .

.Francisco Félix de Souza, mercador de escravos. Rio de Janeiro: Nova Fronteira/Ed.Uerj,

SILVA, G. G. da. Engenbo e arquitetura. Morfologia dos edifícios dos antigos engenbos de açúcar pernambucanos 1990. Tese (Doutorado) - Faculdade de Arquitetura e Urbanismo, Universidade de São Paulo, São Paulo, 1990, 2v.

SINGLETON,T.A. Slavery and Spacial Dialetics on Cuban Coffee Plantations. World Archaeology, Londres, v. 33, n. 1, p. 98-114, jun. 2001.

SMITH, H. H. Uma fazenda de café no tempo do Império. Rio de Janeiro: Departamento Nacional do Café, 1941.

TAVARES, L. H. D. Comércio proibido de escravos. São Paulo: Ática, 1988.

TOMICH, D. Through the Prism of Slavery. Labor, Capital, and World Economy. Boulder, Co: Rowman \& Littlefield Publ., 2004.

TSCHUDI, J. J. von. Viagem às províncias do Rio de Janeiro e São Paulo. São Paulo: Edusp; Belo Horizonte: Itatiaia, 1980.

VERGER, P. Fluxo e refluxo do tráfico de escravos entre o Golfo de Benin e a Babia de Todos os Santos, dos séculos XVII a XIX. São Paulo: Corrupio, 1987.

VLACH, J. The Afro-American Tradition in Decorative Arts. Athens:The University of Georgia Press, 1990.

Back of the Big House.The Architecture of Plantation Slavery. Chapel Hill:The University of North Carolina Press, 1993.

WAGNER, R.; BANDEIRA, J. Viagem ao Brasil nas aquarelas de Thomas Ender: 1817-1818. Petrópolis: Kapa Editorial, 2000.

WATTS, D. Las Indias Occidentales. Modalidades de desarrollo, cultura y cambio Medioambiental desde 1492. Madrid:Alianza Editorial, 1992.

WERNECK, F. P. de L. Memória sobre a fundação de uma fazenda na província do Rio de Janeiro (1847) (E. Silva, org.). Rio de Janeiro: Fundação Casa de Rui Barbosa/Senado Federal, 1985.

Artigo apresentado em 07/2005. Aprovado em 10/2005. 